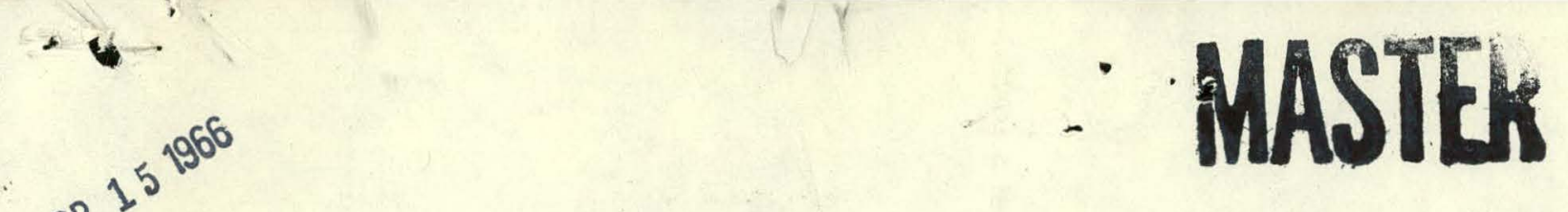

AR 2

BNL 10109

Cont-660208-16

RELEASED FOR ANNOUNCEMENT

IN NUCLEAR SCIENCE ABSTRACTS

\section{CFSTI PRICES}

H.C. $\$ 2.00 ; M N .50$

\title{
BROOKHAVEN NATIONAL LABORATORY PROCESS \\ FOR THE \\ CONTINUOUS CONVERSION OF HIGH-LEVEL \\ RADIOACTIVE WASTE TO PHOSPHATE GLASS
}

E. J. Tuthill, G. G. Weth,

L. C. Emma, G. Strickland and L. P. Hatch

Brookhaven National Laboratory

Upton, New York

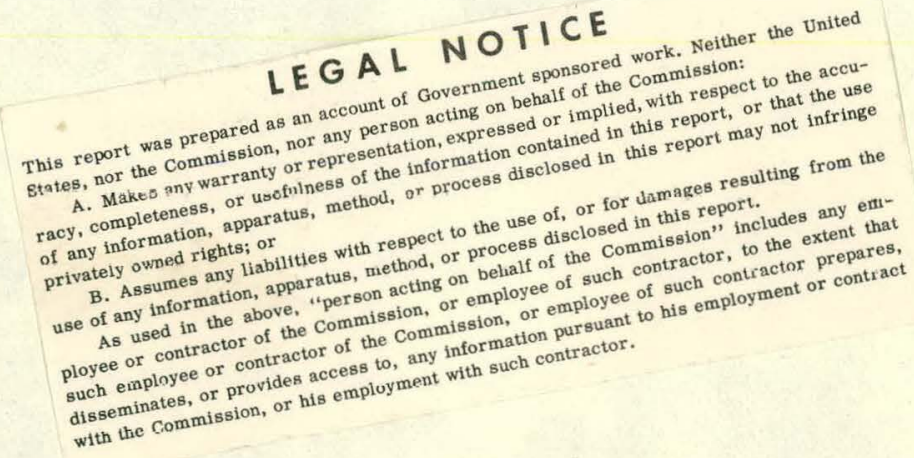




\section{DISCLAIMER}

This report was prepared as an account of work sponsored by an agency of the United States Government. Neither the United States Government nor any agency Thereof, nor any of their employees, makes any warranty, express or implied, or assumes any legal liability or responsibility for the accuracy, completeness, or usefulness of any information, apparatus, product, or process disclosed, or represents that its use would not infringe privately owned rights. Reference herein to any specific commercial product, process, or service by trade name, trademark, manufacturer, or otherwise does not necessarily constitute or imply its endorsement, recommendation, or favoring by the United States Government or any agency thereof. The views and opinions of authors expressed herein do not necessarily state or reflect those of the United States Government or any agency thereof. 


\section{DISCLAIMER}

Portions of this document may be illegible in electronic image products. Images are produced from the best available original document. 


\section{BROOKHAVEN NATIONAL LABORATORY PROCESS \\ FOR THE \\ CONTINUOUS CONVERSION OF HIGH-LEVEL \\ RADIOACTIVE WASTE TO PHOSPHATE GLASS}

E. J. Tuthill, G. G. Weth

I. C. Emma, G. Strickland and L. P. Hatch

Brookhaven National Laboratory

Upton, New York

\section{ABSTRACT}

The conversion of high-level radioactive wastes to phosphate glass offers a promising means of incorporating fission products in stable media suitable for ultimate disposal. In the Brookhaven process, phosphoric acid is added to the aqueous waste and the solution converted. to phosphate glass in a continuous operation upon raising the temperature in two steps to $1100^{\circ} \mathrm{C}-1200^{\circ} \mathrm{C}$. The process has been tested on a pilot plant scale for some 3000 hours.

The report presents the results of the Brookhaven. investigation on the development of the phosphate glass process with emphasis on the performance characteristics of the individual process units.

\section{INTRODUCT ION}

One of the most promising approaches to the problem of ultimate disposal of high level radioactive wastes is based on the fixation of the fission products in stable solid media and the storage of the solid in well isolated environments such as cavities in deep-lying salt formations. The development of a process for the incorporation of the fission products. in phosphate glas.s as a means of carrying out the fixation step in this disposal method: has been carried on at Brookhaven $\mathrm{Na}-$ tional Laboratory (BNL) for the past six years.

The phosphate glass process was selected for development willi llie view to utilizing the advantagos inherent in a con= tinuous process as well as to obtaining a stable end product. 
A basic factor in selecting the process, therefore, was that it could be carried out in an all-liquid system with the materials transferred from one process vessel to another by virtue of pressure difference.

The phosphate glass process is carried out in two steps, an evaporation-denitration step, and a glass-forming step. The feed is prepared, in the case of Purex-type waste, for example, by mixing orthophosphoric acid with the waste solution in the proportion 1:1, metal cation equivalents to moles of $\mathrm{H}_{3} \mathrm{PO}_{4}$.

In the evaporation-denitration step, water and nitric acid are volatilized from the solution at temperatures in the range $130^{\circ} \mathrm{C}$ to $160^{\circ} \mathrm{C}$ to give a volume reduction by a factor of about 10 , and a nitrate removal on the order of $90 \%$. Since nitrate removal at this point is beneficial to the subsequent glass-forming step, the volatilization is continued until the increase in viscosity of the solution becomes the limiting factor. The off-gases from the evaporator are conducted to a water-cooled condenser.

In the glass-forming step the solution discharged from the evaporator is fed continuously to a platinum crucible containing a pool of molten glass maintained at a temperature of $1100^{\circ}-1200^{\circ} \mathrm{C}$. After a residence period in the crucible the newly-formed glass is discharged, by displacement, to a receiver vessel where the rate of addition of molten glass and the rate of cooling are controlled to allow the build-up of a somewhat homogeneous mass of solidified product. Off-gases from the crucible are made up largely of sulfuric and nitric acids together with small concentrations of simulated fission products, particularly ruthenium. At the present stage in the development of the process the melter off-gases are passed to a water-cooled condenser, but the potential problem of treatment and disposal of the contaminated, sulfaterich, condensate is largely unresolved. The question of the fate of the sulfate component of high level radioactive wastes has been raised in a rather basic sense, actually, in the consideration of a number of the high temperature processes proposed for fixation of fission products in stable solids.

This report presents a discussion of the results of studies carried out at BNL on the development of the phosphate glass process. Simulated Purex waste was used in most of the studies and both bench-scale and pilot-plant scale equipment was employed.

\section{BENCH-SCALE EXPERIMENTS}

The bench-scale studies on the phosphate glass process have been carried out, for the most part, with the equipment shown in Fig. 1 and in accordance with the flow diagram shown in Fig. 2 . The feed tank, 6 in. in diameter and $23 \mathrm{in.} \mathrm{high,} \mathrm{is} \mathrm{connected}$ 
through a bottom outlet to an external piping circuit having an in-line centrifugal pump and a side take-off line connected through a magnetically operated splitter. The splitter serves to divert a minor portion of the stream to the evaporator while the major portion if recirculated back through the feed tank, thereby maintaining good distribution of the small complement of solids usually present in the feed solution. The evaporator, 4 in. in diameter and 6 in. in height, is constructed of 304 stainless steel and has a hold-up capacity of $200 \mathrm{ml}$. Excess freeboard is provided to allow for vapor disengagement and to reduce the tendency for entrainment of liquid droplets in the off-gas stream.' In the evaporation step the major portions of the nitric acid and water are removed at temperatures varying from $130^{\circ} \mathrm{C}$ and $160^{\circ} \mathrm{C}$, depending largely on the water content of the feed. The evaporator is equipped with a weir which, by maintaining a constant liquid level, essentially provides for uniform residence time. The concentrated solution flows to the platinum crucible (melter) where it is introduced through a feeder terminating 2 in. above the glass pool. The feeder is cooled by means of a water jacket such that the temperature of the feed solution decreases slightly in its passage through the central tube. The purpose of the feeder is to conduct the solution to a point near the surface of the molten glass pool without boiling, before releasing it to the high temperature environment, thus minimizing the extent of spattering on the wall of the crucible. The platinum crucible is $3 \mathrm{in.}$ in diameter, $10 \mathrm{in}$. in length and has a $40 \mathrm{mil}$ wall thickness. The glass product flows from the melter over a weir which maintains the pool with a depth of 3 in. The off-gases from the melter are composed mainly of sulfuric acid and water vapors together with some residual nitric acid and a small amount of phosphoric acid. The off-gases flow through a 1-in. platinum tube connected at the top of the melter to a water-cooled glass condenser. Noncondensible gases are passed through a scrubber and thence to the house vacuum system.

One of the objectives in carrying out the bench-scale experiments was to determine the course of the major components of the feed solution in the phosphate glass process and their distribution in the end products, i.e. in the glass and the offgas condensates.

In an early bench-scale experiment the feed solution was prepared by mixing 10 liters of simulated Purex waste. (1WW Hanford 1960), representing raw waste already concentrated by a factor of 10, with 2 liters of $85 \% \mathrm{H}_{3} \mathrm{PO}_{4}$. The sululion was fed continuously to the evaporator which was operated at a temperature of $130^{\circ} \mathrm{C}$. With a residence time in the evaporator. of about 1 hour, the solution volume was reduced by a factor of . 3.8. Analysis of the off-gas condensate showed that most of the nitrate was removed in the evaporation step while only trace amounts of the phosphate and sulfate together with some $2 \%$ of 
the ruthenium were carried over. The syrupy green liquid from the evaporator flowed smoothly through the feeder to the glass pool which was maintained at a temperature of about $1100^{\circ} \mathrm{C}$. No build-up of deposits on the wall of the crucible was encountered. Residence time in the glass pool was normally 4 hours but the product remained free-flowing with much longer residence periods. only small fractions of the total nitrates and phosphates fed to the system were found in the melter off-gas condensate but most of the sulfate and about $6 \%$ of the $\mathrm{Ru}$ were present. Fe, $\mathrm{Na}$ and $\mathrm{Cs}^{*}$ were present in the condensate only in trace amounts and the carryover of these constituents was attributed mainly to entrainment of liquid droplets.

It was noted, in the course of bringing the evaporator up to operating temperature at the beginning of a run that the solution passed through a foaming stage in a temperature range well below the operating level. After the initial start-up period, however, the evaporator continued to operate smoothly without further foaming.

Use of the specially designed solution feeder was found to be highly beneficial to the operation of the melter and any spattering of the feed solution on the crucible wall, which was more or less confined to the region between the feeder and the glass pool, resulted in the formation of layers of molten glass which readily drained away. The solution feeder was maintained at a temperature of $100^{\circ} \mathrm{C}$, thus eliminating any tendency for overheating of the solution or caking of the ingredients inside the feeder. The time interval required for actual formation of the glass was estimated to be roughly that required to raise the temperature of the components to the $1100^{\circ} \mathrm{C}$ level as they fluxed with the molten glass in the pool.

In later experiments using a new waste formulation, based on information supplied by Hanford, an analysis of the glass product showed that essentially all the phosphate and no detectable amounts of nitrogen or sulfur were found in the glass. The presence of $99.9 \%$ of the $\mathrm{Fe}$ in the glass indicated that the transfer of components by entrainment of solids or liquids in the offgases from the evaporator and the melter, was not a significant factor.

Several experiments were then carried out using a further modified feed composition as proposed, from more refined estimates of Purex waste, by Hanford (now Battelle. Northwest) personnel. The new composition, shown in Table 1 , is based on

* $\mathrm{Ru}$ and $\mathrm{Cs}$ were added to the waste in abnormal amounts to facilitate chemical analysis. 
80 gallons of waste

ton of $U$ processed

and 10,000 megawatt days/ton $\mathrm{U}$ or $\mathrm{Pu}$ burn-up.

In these experiments performance characteristics of the equipment and the quality of the glass product were considered satisfactory. The results of a typical 16-hour run with the new feed composition are shown in Table 2 . With the evaporator operating at a higher temperature than before, i.e., $152^{\circ}$ to $167^{\circ} \mathrm{C}$, virtually all the nitrate and the mercury were volatilized, while $95 \%$ of the ruthenium was transferred to the melter and retained in the glass.

Since the sulfate component of the waste is readily volatilized in the glass forming step, along with small amounts of fission product, it presents an additional problem of disposal of the contaminated condensate as a secondary waste stream. Sulfate is present in a Purex waste due to the mixing of the effluent of the second cycle of the Purex process, which contains ferrous sulfamate, with that of the first cycle, which contains most of the fission products. However, Purex waste contains no sulfate if reductants other than ferrous sulfamate are used in the process.

The bench-scale unit was then operated in a series of runs with simulated $80 \mathrm{gal} / \mathrm{t}$ on Purex waste made up without the addition of sulfate. The process was carried out smoothly in each of the runs and the distribution of the components in the end products is shown, together with comparative results from experiments with sulfate-containing waste, in Table 3 . With the nonsulfate waste, $98 \%$ of the nitrate was removed in the evaporation step, which was a substantially higher percentage than was removed when sulfate was present. Volume reduction in the evaporation step, at $160^{\circ} \mathrm{C}$, was by a factor of 19 , whereas the factor was 8 with the sulfate present. Since the removal of nitrate and water in the evaporation step reduces the load on the melter, sulfate-free waste appears to lend itself to phosphate glass processing in this regard.

Some major changes in the composition of Purex waste will accompany higher burn-up of the fuel and this will require changes in the amounts of $\mathrm{Fe}, \mathrm{Na}$ and $\mathrm{H}_{3} \mathrm{PO}_{4}$ to be added for carrying out the phosphate glass process. However, no major problems are foreseen in the processing. of these wastes and present plans call for experiments with Purex-type wastes with compositions based on burn-up levels as high as 40,000 MWD/T, as given in Table 4 . To date, Purex $2^{b}$ and purex $C$ have been run in the bench-scale unit with good results.

\section{PILOT PLANT EXPERIMENTS}

On the basis of the results obtained with the bench-scale operations an engineering-scale (pilot) plant (see Fig. 3) was constructed and put into operation in January 1963. Although the larger scale plant is basically similar to the bench-scale unit, new design features were incorporated and a number of sensitive parameters such as hold-up volumes, sizes of transfer 
lines, uniformity of temperature, etc. could be given independent design consideration. In addition to providing for carrying out a more comprehensive study of the phosphate glass process, the purpose in building the larger scale plant was to introduce wider use of instrumentation in the integrated operation and to develop corrective means and procedures suitable for use, under remote control, in cases of maloperation or malfunction of equipment. A further and most important purpose was to carry out an extensive testing of the platinum crucible both with respect to corrosion resistance and structural strength at the high temperatures.

In the pilot plant, represented in Fig. 2, the feed solution, prepared by the addition of phosphoric acid to the simulated waste, is stored in three tanks located immediately outside the plant enclosure. The mixing tank, constructed of 316 stainless steel, has a capacity of 1000 liters. The two hold tanks are glass lined and have a combined capacity of 1200 liters. From the hold tanks the solution is pumped to a 100 liter stainless steel feed tank which, as in the bench-scale unit, is interconnected with an external piping circuit equipped with a magnetically-operated splitter valve to divert a small portion of the recirculated stream to the evaporator.

The evaporator consists essentially of a cylindrical vessel, $12 \mathrm{in.}$ in diameter and $24 \mathrm{in.} \mathrm{high,} \mathrm{constructed} \mathrm{of} 1 / 8 \mathrm{in}$. thick. Carpenter 20, and equipped with two internal steam coils. The coils, one concentric with the other, are made up of $1 / 2-i n$. $0 . d$. 304 stainless steel tubing having coil diameters of 8 in. and 10 in. and a total heat transfer area of $9 \mathrm{ft}^{2}$. The coils are independently connected to the steam supply and are operated totally submerged, with a hold-up volume of 27 liters. Auxiliary electrical resistance heating is provided at the top of the evaporator to prevent refluxing of volatile components. The evaporator is normally operated within the temperature range $130^{\circ} \mathrm{C}$ to $160^{\circ} \mathrm{C}$, the level being selected according to the composition nf the waste. The off-gases, consisting mainly of nitric acid and water vapors, are exhausted through a 2-in. Iine to a water-cooled condenser and the condensate is collected in a 100 liter stainless steel tank. From the evaporator the thickened solution flows over a 3/4-in. standpipe to the melter where it is introduced through a jacketed feeder which is cooled by water boiling under total reflux. The feeder, $1-3 / 4 \mathrm{in}$. in diameter by 14 in. long, is constructed entirely of platinum and is positioned in the crucible so that the solution is introduced at a point about 6 in. above the glass pool. Thus, with the very short period of free fall to the glass pool, the extent of spattering of the solution on sudden exposure to the high temperature environment is minimal. Usually the outside of the feeder is kept clean by the action of the condensing $\mathrm{H}_{2} \mathrm{SO}_{4}$. Occasionally, however, deposits have built up on the feeder and a successful remedy has been to cut off the flow of the feed and to allow the water in the cooling 
jacket to boil out of the system, thereby causing the temperature of the feeder to rise sharply and reach a level sufficient for the deposits to convert to a molten glass and drain away.

The melter, shown in Fig. 4 , is 8 in. in diameter, 24 in. high with a $40 \mathrm{mil}$ wall thickness in the upper region and an 80 mil thickness in the lower region. The unit is heated by a 26 kilowatt resistance-type (globar) furnace and is maintained at a temperature of $1100^{\circ} \mathrm{C}$ to $1200^{\circ} \mathrm{C}$. Primarily, the melter unit serves to maintain a pool of molten glass at the high temperature and provides for the steady input of heat so that the feed from the evaporator, which for an initial period resides in an island at the surface of the pool, is itself converted to glass and becomes part of the pool. The transformation from this relatively cool feed to the molten glass, together with the evolution of volatile components, is considered to be the crucial step in the entire phosphate glass process. The glass pool provides an excellent medium for carrying out this transformation without the difficulties which normally accompany such radical changes-of-state when permitted to occur in the region of a heated container wall.

The melter off-gases are conducted through a 2-in. platinum line to a Nionel condenser and the condensate is stored in a 100 liter stainless steel tank. Liquid droplets and solids entrained in the off-gases are removed in a gas scrubber and the noncondensible gases are discharged through a stack.

The glass product flows from the crucible through a freestanding discharge pipe containing a trap which, in turn, serves as a seal between the atmosphere above the glass pool and that in the receiver vessel in case the discharge tube is emptied as a result of an interruption in the flow of feed to the crucible. The crucible is also equipped with an independent discharge line, containing a freeze valve, which is used only for complete drainage of the vessel. Twenty-four radial platinum fins are welded to the inner wall of the crucible to promote circulation and convective transfer of heat to the ponl. The crucible is supported both at the top by means of adjustable jacks attached to the top flange and at the bottom where the remaining portion of its weight is transferred to a ceramic plate. This means of supporting the present, or second, crucible used in the pilot plant was selected in order to avoid any recurrence of the highly adverse condition encountered in the testing of the first crucible. In that case an outer Inconel 702 support vessel was used in conjunction with a coating of aluminum oxide on the crucible to separate the platinum from the metals of the support vessel. Two design schemes were employed, one in which the support vessel extended the full length of the crucible and the other in which it extended upward only 8 in. from the bottom. During a prolonged run a crack developed in the discharge Iine, which contained the freeze valve, resulting in a continuous seepage of molten glass in a region located about 2 in. below 
the bottom of the crucible. It was apparent on subsequent examination of the crucible, however, that some molten glass had migrated upward along the tube wall to the zone of higher temperature at the base of the crucible and that it had entered the region between the Inconel 702 vessel and the platinum crucible and formed a bridge between the metals. The result was that a breakdown of the platinum wall occurred in an area of some $2 \mathrm{sq}$. in. It was apparent that metals in the Inconel reacted with the molten phosphate to form elemental phosphorus which, in turn, combined with the platinum to form lower melting alloys. The cause of the crack in the discharge tube was later attributed to stresses due to straightening out the tube after a sharp bend had occurred as a result of mishandling the crucible in transit to the welding.shop. Although the damaged platinum crucible could have been repaired for reuse, the decision was made to install a new crucible in the plant, using a different means of support such that any recurrence of the conditions required for chemical reduction of the phosphate would be considered most unlikely.

With respect to the structural strength of platinum at the high temperatures, an observation was made on the condition of the crucible, during the course of an extended run, which may have particular significance. The observation reflects on the crucible support, which, as already noted, was by means of a ceramic plate resting on hlocks at the bottom and a flange at the top with the adjustable jacks to take up a portion of the weight load. At one point in the run it was noted that the ceramic plate was not in contact with the crucible on one side over approximately one-half the bottom area. After an additional 1400 hours of operation, however, examination of the crucible revealed that it had become only slightly distended in the unsupported area. This finding indicates that the platinum (M-l grade) has considerably more strength at the high temperatures than was indicated from calculations based on extrapolation of published data from tests made at lower temperature.

A second observation was made with reference to the effects of allowing the melter to cool without first discharging the pool of molten glass. In previous bench-scale operation with 2 in. and 3 in. diameter crucibles it had been found, after many thermal cycles, that when solidification took place initially in the top zone of the glass pool and progressed downward, the side walls were pulled inward as the bulk of the glass cooled and contracted. For this reasnn, the normal operating procedure with the pilot plant has been to drain the crucible through the freeze-valve line before the furnace was turned off. However, during a power failure which occurred while the plant was unattended, the melter with its glass contents cooled to room temperature with no apparent distortion of or damage to the crucible. In this case the glass undoubtedly cooled slowly because of the larger heat reservoir in the glass itself and in the structure of the resistance furnace. 
The entire mass of glass remained plastic long enough to permit the formation of the usual "pipe", or surface depression, which compensated for the contraction in volume.

A third observation was made with respect to the properties of the glass itself. After an extended period of standing idle at $1200^{\circ} \mathrm{C}$, it was found that the contents of the melter had become hardened and that it would not flow. However, it was found by chemical analysis that the contents had become phosphate deficient and this was attributed to loss through volatilization. Iron phosphate, in excess of the amount required to restore the phosphate to its original level, was added and the crucible was reheated to $1200^{\circ} \mathrm{C}$. After a period of approximately 1 hour the contents were agin of a fluid consistency and the material flowed readily through the drain line. In light of this experience the melter temperature is maintained at $800^{\circ} \mathrm{C}$ to $900^{\circ} \mathrm{C}$ during standby periods since at this temperature there is no signficant volatilization of phosphate.

Since the fall of 1963 several extended runs of the pilot plant have been carried out under conditions of continuous operation and process equilibrium. The runs had a three-fold purpose; i.e., to provide data for the establishment of more comprehensive design criteria, to point out the needs for additional plant instrumentation, and to more thoroughly determine operational parameters as required for process control. The early runs were generally of 16 to 32 hours duration. In the spring of 1964 a 100-hour run was made with no serious process difficulties and the data obtained were used as a basis for the design of a demonstration prototype plant which was constructed during 1964 at Battelle Northwest Laboratories (BNWL). For the most part, however, the plant has been operated for short periods for the purpose of studying process variables and for logging hours on the individual equipment units.

According to material balance studies made from the extended runs with the pilot plant, the distribution of components of the feed in the end products differed only slightly from that found under comparable conditions in the bench-scale experiments. For example, with Purex-type waste, $96 \%$ of the nitrate was removed in the evaporation step at $160^{\circ} \mathrm{C}$ with a volume reduction factor of 7. The volume reduction factor in the melter step was about 3, qiving an over-all volume reduction, original feed to glass for $80 \mathrm{gal} /$ tonne U Purex waste, by a factor of about 20 . A total of some 43.5 cubic feet of glass has been produced in the plant from 4500 gallons of feed (equivalent to approximately 57 tons of uranium processed). The accumulated service hours on the various process units are listed in Table 4.

To obtain information on the terminal distribution of the fission products in the Phosphate Glass Process, a cooperative experiment was carried out with BNWL using high level radioactive Purex waste. An additional objective in the experiment was to 
provide samples for studying the physical characteristics of radioactive phosphate glasses. Two flow schemes were used in these hotcell experiments as shown in Fig. 5. Both schemes involved the two basic process steps but they differed in the method of treatment of the off-gases.

With Scheme I the off gases from the evaporator and the melter were combined with a single stream and fed to a fractionator. Nitric acid and water vapor from the top of the fractionator were condensed and collected in a receiver. $\mathrm{H}_{2} \mathrm{SO}_{4}$ was withdrawn from the lower section and stored. Noncondensibles were further decontaminated on passing througho a second condenser, with steam added upstream to enhance the removal of entrained material. With Scheme II, represented at the right of the dotted line in Fig. 5, the off gases from the evaporator and those from the melter were treated as individual streams and were separately fed to condensers, and the residual gases were passed to the filter train for final decontamination.

Results of the hot-cell experiments are given in detail in Hanford Reports 84467 and 84603 but are summarized briefly herein. The metal ions, including those of the fission products, were largely retained in the glass (the major exception being ruthenium which showed $94 \%$ to $99 \%$ retention depending upon the water content of the melter feed. The concentration of sulfate in the waste also may have affected ruthenium retention in the glass since most of the ruthenium not retained was found in the off-gas condensate which was mainly $\mathrm{H}_{2} \mathrm{SO}_{4}$. Some cerium also appeared in the off-gas condensate and the amounts were about $1 \%$ of that in the feed, however, these data are inconclusive owing to high cerium contamination in the cell from an earlier experiment. The loss of other fission products $\mathrm{Cs}^{137}$ and $\mathrm{Zr}-\mathrm{Nb}^{95}$ averaged less than $0.1 \%$ of the original amounts. Essentially all the material lost in the process steps were trapped in the condensates, and the carry over of trace material in the noncondensible gas effluent was found to be a factor of $10^{8}$ below the combined amount of these materials in the feed. Decontamination in the final filters was by factors in excess of 109, usually beyond the detection limits.

The equipment used in the hot cell experiments is shown in Fig. 6. The radioactive glass product shown in Fig. 7 contained 200 curies of activity and was made from. 3 liters of $U$ waste ( 56 gal/ton). The phosphate glasses made during the hot-cell runs are presently being used in physical and chemical studies at BNWL to determine leachability of fission products, devitrification etc.

\section{LABORATORY STUDIES}

Phosphate glasses of varying composition were examined for extent of devitrification and tested for leachability with respect to $\mathrm{Sr}$ and $\mathrm{Ce}$ in $\mathrm{H}_{2} \mathrm{O}$ and $\mathrm{pH}_{4} \mathrm{HNO}_{3}$. The results showed that the 
phosphate glass compared favorably, with other types of glass being considered for high level waste disposal both in the United states and abroad. Leach rates of the trace cations $\mathrm{Sr}^{90}$ and $\mathrm{Ce}^{144}$ from samples of Purex-phosphate glass are shown in Tables 6 and 7 and these values together with the qualities of uniformity and absence of crystalline areas for the respective samples, were used as criteria in selecting the glass formulations shown in the triangular plot, Fig. 8 .

The iron to sodium ratio is constant along the line connecting the point marked 1 WW with $100 \% \mathrm{P}_{2} \mathrm{O}_{5}$ and is roughly the same. as is found in a typical Purex waste. Actually, the values of mole percent for the $\mathrm{Fe}$ component are somewhat in excess of the true values in that they also include the values for fission product and corrosion product cations.' The reason for this grouping was because the $\mathrm{Fe}$ is normally present in very much higher concentrations than the other multi-valent cations. In addition, $\mathrm{Fe}$ and $\mathrm{Na}$ were selected as component variables since they may be considered, respectively, the chief glass network former and network ender. Glasses showing no signs of devitrification were made at $1100^{\circ} \mathrm{C}$ with the mole percent of $\mathrm{P}_{2} \mathrm{O}_{5}$, considering the three components only, in the neighborhood of 70 . Experiments involving the formation of phosphate glasses from aluminum nitrate (Redox) waste indicated that good glass could be made at $1100^{\circ} \mathrm{C}$ by the addition of iron and phosphate such that the $\mathrm{Al}_{2} \mathrm{O}_{3}: \mathrm{Fe}_{2} \mathrm{O}_{3}: \mathrm{P}_{2} \mathrm{O}_{5}: \mathrm{NaO}$ mole relationships were $1.0: 0.63: 4.5: 0.25$ as shown in $\mathrm{Fig}$. 9 . From the results of the foregoing studies it was evident that phosphate glass formulations could be selected with considerable allowance for variation in the concentrations of the waste cations.

Although the selection of platinum as the material of construction for the melter was made early in the development program, a considerable number of bench-scale experiments were carried out with the use of ceramic crucibles. In an independent test to determine corrosion resistance of various ceramic materials, crucibles made up of alumina, zirconia, magnesia, and Mullite were exposed to phusplule glass at $1200^{\circ} \mathrm{C}$ for periods of 350 hours. Only the high density alumina, such as Coors $A D-99$ and Morganite, showed no signs of corrosive attack. Accordingly, alumina crucibles were used in the bench-scale experiments and generally they were $2-1 / 2$ in. i.d. $x 18$ in. long with $1 / 8$ in. thick walls and bottom. Actually, the disposal scheme at that point in the development was that a crucible would be used for one filling only and would serve as a permanent container for the glass.

On the basis of the results of the bench-scale experiments a high density alumina crucible was installed in the pilot plant in accordance with the original design of the plant. The crucible shown in Fig. 10 was 5 in. i.d. by $6 \mathrm{ft}$. Iong with a wall thickriess of $1 / 4 \mathrm{in.}$ However, during the first rin, which was for a period of about 18 hours, a large crack developed in the crucible wall and the run was terminated. The conclusion was made that 
the failure had occurred because of excessive thermal stress and that the ceramic did not show good promise as a material of construction for the crucibles, at least for those of pilot plant scale of size. Moreover, a tentative decision had already been made to look more to the use of a platinum crucible and the continuous mode of operation.

Although the major testing of platinum as a material of construction for the crucible has been carried on as an integral part of the bench-scale and pilot-plant operations, some independent corrosion and strength studies have been made on platinum and its alloys. Test specimens of $100 \% \mathrm{Pt}, \mathrm{Pt}-2-1 / 2 \% \mathrm{Rh}, \mathrm{Pt}-5 \% \mathrm{Rh}$, Pt-10\% Rh, Pt-5\% Ir and Pt-3\% Au were exposed to phosphate glass at $1100^{\circ} \mathrm{C}$ for 3000 hours. From the results shown in Fig. 1l, it was evident that pure platinum and $\mathrm{Pt}-3.9 \% \mathrm{Au}$ showed the greatest resistance to attack. The other alloys showed intergranular corrosion.

Two platinum coupons are presently being tested at $1200^{\circ} \mathrm{C}$ with respect to creep strength and stress-to-rupture at 50 psi and 100 psi, respectively. The coupon under 50 psi showed $1.38 \%$ creep in the first 1800 hours and no further creep in an. additional 300 hours. The coupon under 100 psi showed $1.42 \%$ creep in the first 340 hours and a negative creep of $0.6 \%$ in an additional 1410 hours, or an over-all positive crecp of $0.82 \%$ in 17.50 hours, The tests are continuing.

Some exploratory investigations have been made with respect to the problem of treatment of condensates of the melter off gases. One approach was based on the conversion of the bulk of the condensate to a low level waste by means of distillation and the return of the still bottoms (as a liquid) to the melter. Experiments showed that by increasing the distillation temperature, in steps, to $350^{\circ} \mathrm{C}$ virtually all the nitric acid was volatilized along with $91.2 \%$ of the $\mathrm{H}_{2} \mathrm{SO}_{4}$ and. $0.7 \%$ of the $\mathrm{H}_{3} \mathrm{PO}_{4}$. The volume reduction was by a factor of 28. The remaining solution was clear and free flowing and formed a glass body, without further additions of chemicals, when heated to $1100^{\circ} \mathrm{C}$. In a parallel experiment to determine the course of individual fission products during the distillation step, condensate with added cerium spiked with $\mathrm{Ce}^{144}\left(5.0 \times 10^{7} \mathrm{~d} / \mathrm{m} / \mathrm{ml}\right)$ was used. As the temperature increased samples were taken at $50^{\circ} \mathrm{C}$ intervals until the reduction in volume was by a factor of 10. The still bottoms at this point were in a thickened, but liquid, state and would flow readily. The decontamination factors with respect to Ce are shown in Table 8 .

Another method which was investigated was the high temperature gas-phase reduction of $\mathrm{SO}_{3}$ to $\mathrm{SO}_{2}$ followed by cold water dissolution of the $\mathrm{SO}_{2}$. The $\mathrm{SO}_{2}$, in turn, was to be volatilized from the water solution upon heating to $90^{\circ} \mathrm{C}$. The reducing gas was fed into a quartz tube, heated initially by external means, along with a mixture of simulated melter off gases and air. 
Propane, methane and co were used successfully in the experiments but $C O$ proved to be the easiest to handle. Infrared analysis showed that the ratio of $\mathrm{SO}_{2}$ to $\mathrm{COS}$ could be controlled by varying the concentration of $\mathrm{CO}$, as shown in $\mathrm{Fig}$. 12. Although the $\mathrm{SO}_{3}$ could not be measured directly with the infrared technique, the conversion, as determined on the basis of wet chemical analysis of $\mathrm{SO}_{2}$, was found to be about $97 \%$ complete.

Although the reduction of $\mathrm{SO}_{3}$ to $\mathrm{SO}_{2}$ offers a direct means of disposing of the sulfate as a gaseous product the reduction step must be carried out at temperatures above $1000^{\circ} \mathrm{C}$. Therefore, the lower temperature processes, such as the direct volatilization of $\mathrm{SO}_{3}$ and $\mathrm{H}_{2} \mathrm{O}$ from the melter off-gas condensate, will be more extensively investigated. 
TABLE 1

Prototype - Design Basis Feed

$$
\text { Type - Purex }
$$

\section{Cations}

$\begin{array}{ll}\mathrm{H}^{+} & \text {to balance } \underline{\mathrm{M}} \\ \mathrm{Na} & 0.40 \underline{\mathrm{M}} \\ \mathrm{Fe} & 9.1 \times 10^{-2} \underline{\mathrm{M}} \\ \mathrm{Al} & 4.5 \times 10^{-2} \underline{\mathrm{M}} \\ \mathrm{Cr} & 1.8 \times 10^{-2} \underline{\mathrm{M}} \\ \mathrm{Ni} & 0.9 \times 10^{-2} \underline{\mathrm{M}} \\ \mathrm{U} & 0.06 \times 10^{-2} \underline{\mathrm{M}} \\ \mathrm{Hg} & 0.03 \times 10^{-2} \underline{\mathrm{M}}\end{array}$

Anions

$\begin{array}{ll}\mathrm{NO}_{3} & 5.8 \mathrm{M} \\ \mathrm{SO}_{4} & 0.137 \\ \mathrm{SiO}_{2} & 0.57 \times 10^{-2} \\ \mathrm{PO}_{4} & 0.45 \times 10^{-2}\end{array}$

$\underline{F P^{\prime} S}$

$\mathrm{Zr}$

$2.1 \times 10^{-2} \underline{\mathrm{M}}$

$\mathrm{MO}+\mathrm{TC}$

$2.5 \times 10^{-2} \mathrm{M}$

$Y+R e$

$4.5 \times 10^{-2} \underline{M}$

$\mathrm{Rb}+\mathrm{Cs}$

$1.4 \times 10^{-2} \underline{\mathrm{M}}$

$\mathrm{Sr}+\mathrm{Ba}$

$1.1 \times 10^{-2} \underline{\mathrm{M}}$

RuRhPd

$2.8 \times 10^{-2} \underline{\mathrm{M}}$

Volume

$333 \mathrm{~L} /$ Tonne

(80 gal/ton)

MWD/Tonne

10,000

(Exposure Equiv.) 
TABLE 2

BENCH SCALE PUREX 80 GAL. PER TON U

Run Mar. 31 - Apr. 2, 1964

\begin{tabular}{|c|c|c|c|c|c|c|c|c|c|c|c|c|c|c|}
\hline & $\mathrm{g}$ & $\%$ & B_. & $\%$ & g & $\%$ & 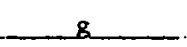 & $\%$ & $\mathrm{mg}$ & $\%$ & g & $\%$ & $\mathrm{~g}$ & $\%$ \\
\hline \multicolumn{15}{|l|}{ In } \\
\hline Feed & 586.08 & & 112.64 & . 0 & 313.28 & & 43.5 & & 475.20 & & 21.21 & & 1.056 & . \\
\hline \multicolumn{15}{|l|}{$\underline{\text { out }}$} \\
\hline Evaporator & $<1 \mathrm{mg} / \mathrm{g}$ sample & $\cdot$ & 9.15 & 8.12 & 21.8 & 6.96 & 3.14 & 7.76 & None Detected & & 1.59 & 7.5 & 0.086 & 8.15 \\
\hline Evap. Cond. & 564.26 & 96.3 & Hone Detected & & $<0.03 \mathrm{mg} / \mathrm{ml}$ sample & & Tone Detected & & 523.05 & 110.00 & 0.24 & 1.13 & $<0.91 \mu \mathrm{g} / \mathrm{ml}$ & \\
\hline Melter Cond. & 5.65 & .97 & 92.88 & 82.5 & 0.16 & .05 & 0.02 & .05 & 9.72 & 2.04 & 0.36 & 1.70 & .0001 & 0.01 \\
\hline Glass & $<1 \mathrm{mg} / \mathrm{g}$ sample & & None Detected & & 315.61 & 100.6 & 40.34 & 99.50 & None Detected & & 20.29 & 95.50 & 1.187 & 132.4 \\
\hline Cold T=ap & .30 & .05 & 0.74 & 0.66 & 0.33 & 0.11 & 0.0002 & $5 \times 10^{-4}$ & 0.21 & 0.04 & 0.008 & 0.04 & $<0.01 \mu \mathrm{g} / \mathrm{ml}$ & \\
\hline Total Jut & 570.21 & 97.32 & 102.77 & 9128 & 337.9 & 107.72 & $\angle 3.5$ & 107.31 & .532 .98 & 112.08 & 22.49 & 105.87 & 1.2731 & 120.56 \\
\hline
\end{tabular}

Total Feed Processed - 2.8 liters

Total Weight of Glass - $1186 . \mathrm{g}$

Total Volume of Glass - 0.425 1iters

Total Volume of Melt. Ccnd. -0.360 liters

Total Volume of Evap. Cend. - 7.925 liters

Total Volume of cold Trap -0.013 liters

Ratio of Feed to Glass - 8.B:0.425 $=20.7: 1$

Ratio of Evap. Cond. to Me1t. Cond. - 7.925:0.36 - $22: 1$

Density of Glass - $2.79 \mathrm{~g} / \mathrm{ml}$

Total Running Time - 16.5 houss

Avg. Feed Rate $-0.533 \mathrm{~L} / \mathrm{hr}$

Mel ter Temp. $-1180-1200^{\circ} \mathrm{C}$

Evap. Termp. - $152-167^{\circ} \mathrm{C}$ 
Table 3

Nitrogen and Water Distribution in off-Gases

(Sulfate and Nonsulfate Containing Purex Waste)

$\begin{array}{ll}\text { Run } & \begin{array}{c}\text { Type of } \\ \text { Feed }\end{array} \\ 1 & \begin{array}{l}\text { Design Basis } \\ \text { Purex without } \mathrm{SO}_{4}\end{array}\end{array}$

2 Design Basis Purex witr: $\mathrm{SO}_{4}$

3 Design Basis Purex with $\mathrm{SO}_{4}$
Amount of Nitrogen

Evap.

Temp. in Feed in Evap. Cond. in ${ }_{\mathrm{C}}^{\mathrm{a}} \frac{\mathrm{in}}{\mathrm{g}}$

$160 \because 612100$ q

600

98.0

$160 \cdot 644100$

$568 \quad 88.2$

76

11.8

Volume of Condensate

$\begin{array}{llll}167 & 586 & 100 & 580 \quad 99.0^{2}\end{array}$

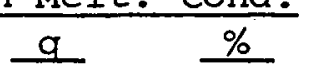

Evaporator
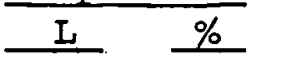

Melter

12

2.0

7.5

$94.6 \quad 0.430 \quad 5.4$

1
4 
Table 4

Purex Waste Composition

\begin{tabular}{|c|c|c|c|c|c|}
\hline $\begin{array}{l}\text { Element } \\
\text { Cations }\end{array}$ & $\begin{array}{l}\text { Purexa } \\
\text { lst Cycle } \\
\text { Molarity }\end{array}$ & $\begin{array}{c}\text { Purex-2 } \\
\text { Combinec } 1 \text { st \& 2nd cycle } \\
\text { Molarity } \\
\end{array}$ & $\begin{array}{c}\text { Purexc } \\
\text { Prototype Design } \\
\text { Basis Feed } \\
\end{array}$ & $\begin{array}{c}\text { Purexd } \\
\text { Prototype Design } \\
\text { Basis Feed } \\
\end{array}$ & $\begin{array}{c}\text { Purex } \\
\text { Prototype Design } \\
\text { Basis Feed } \\
\end{array}$ \\
\hline $\mathrm{Fe} e^{+++}$ & 0.93 & 0.445 & 0.091 & 0.091 & 0.091 \\
\hline $\mathrm{Cr}^{+++}$ & 0.012 & 0.024 & 0.018 & 0.018 & 0.018 \\
\hline $\mathrm{Ni}^{++}$ & C. .005 & 0.010 & 0.009 & 0.009 & 0.009 \\
\hline $\mathrm{Al}^{+++}$ & C. .001 & 0.001 & 0.045 & 0.045 & 0.045 \\
\hline $\mathrm{Na}^{+}$ & 0.138 & $0 . \dot{9} 30$ & 0.40 & 0.40 & 0.40 \\
\hline $\mathrm{U}^{+6}$ & 0.01 & 0.010 & 0.0006 & 0.0006 & 0.0006 \\
\hline $\mathrm{Hg}^{++}$ & $<0.001$ & 0.001 & 0.0003 & 0.0003 & 0.0003 \\
\hline \multicolumn{6}{|l|}{ Anions } \\
\hline $\mathrm{NO}_{3}^{-}=$ & 8.8 & 6.44 & 5.8 & 5.8 & 5.8 \\
\hline $\mathrm{SO}_{4} \equiv$ & - & 0.870 & 0.137 & 0.137 & 0.137 \\
\hline $\mathrm{PO}_{4}$ & & 0.006 & 0.0045 & 0.0045 & 0.0045 \\
\hline $\mathrm{SiO}_{2}$ & 0.01 & 0.010 & 0.0057 & 0.0057 & 0.0057 \\
\hline \multicolumn{6}{|l|}{ F.P. } \\
\hline $\mathrm{Rb}^{+}\left(\mathrm{K}^{+} \mathrm{Sub}.\right)$ & 0.0071 & 0.0071 & 0.006 & 0.012 & 0.024 \\
\hline $\mathrm{Cs}^{+}$ & 0.0345 & 0.0345 & 0.019 & 0.038 & 0.078 \\
\hline $\operatorname{sr}^{++}$ & 0.0155 & 0.0155 & 0.014 & 0.028 & 0.056 \\
\hline $\mathrm{Ba}^{++}$ & 0.0195 & 0.0195 & 0.008 & 0.016 & 0.032 \\
\hline
\end{tabular}


Table 4 (cont)

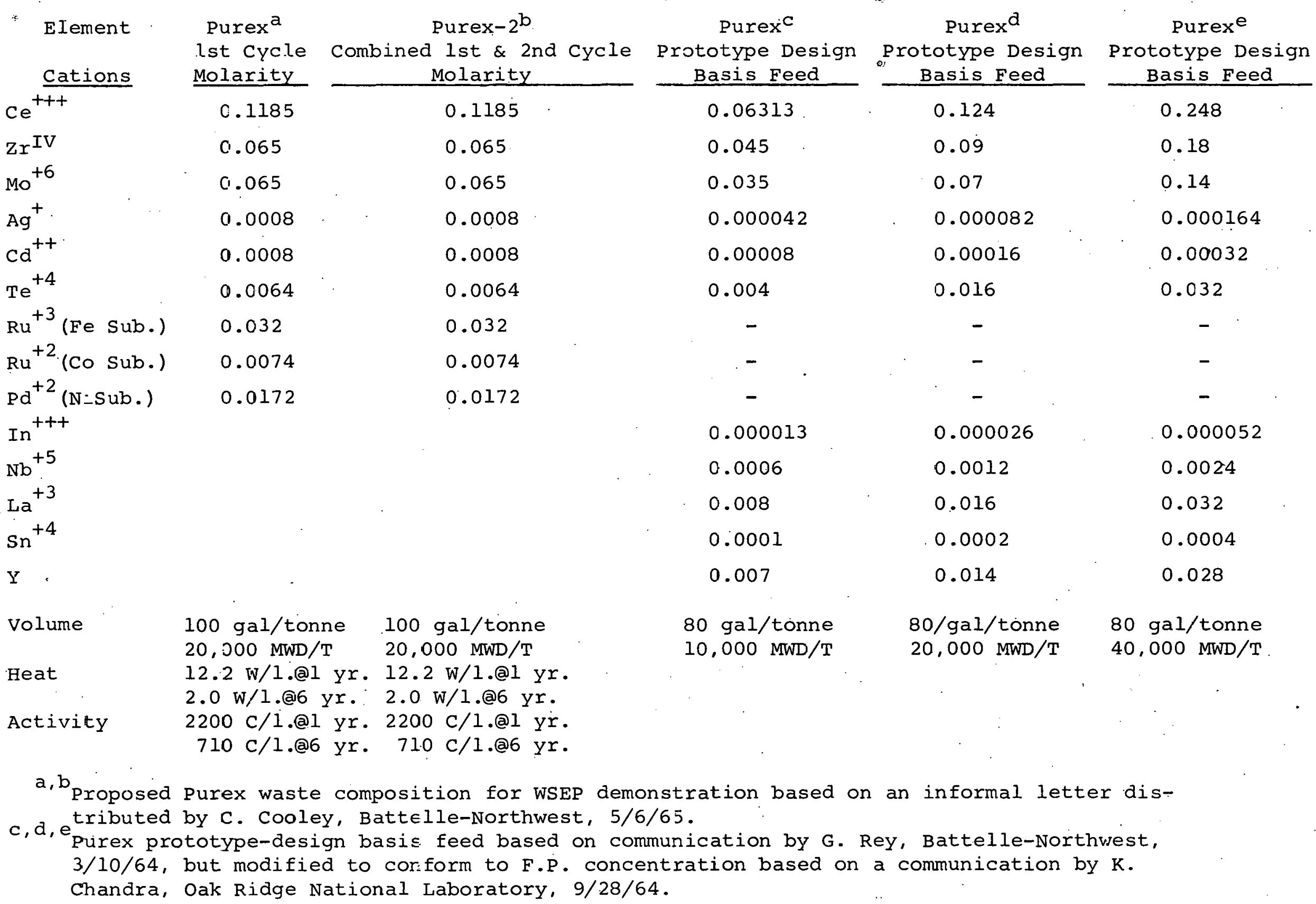


TABLE 5

Equipment Service Record of Plosphate Glass P1ant

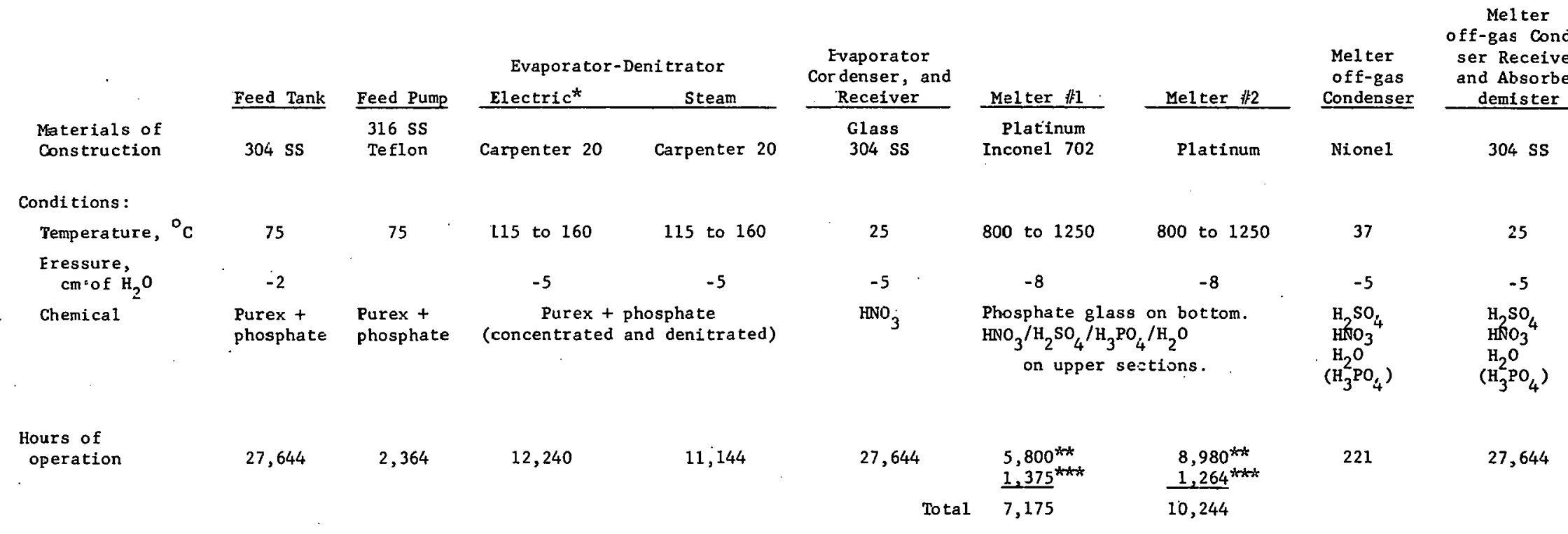

No:e: $8,760 \mathrm{hr}$ in a year.

*Evaporator was originally electrically heated but was later converted to stear heating in the interests of obtaining higher throughputs.

*totween $800^{\circ}$ and $1,250^{\circ} \mathrm{C}$.

* Under glass-forming conditions. 
Table 6

Leaching Rates for Purex Type Phosphate Glass
Containing $\mathrm{Sr}^{90}$ as a Tracer

lst week

$\underline{\mathrm{H}}_{2}$ 으

$\mathrm{pH}_{4} \mathrm{HNO}_{3}$

lst week

$4.78 \times 10^{-7}$

2nd week

$5.45 \times 10^{-7}$

$4.90 \times 10^{-7}$

4 th week

$1.00 \times 10^{-6}$

$1.37 \times 10^{-6}$

5 th week

$1.24 \times 10^{-6}$

$2.27 \times 10^{-6}$

7 th week

$1.59 \times 10^{-6}$

$3.70 \times 10^{-6}$

8th week"

$$
1.51 \times 10^{-6}
$$

$3.90 \times 10^{-6}$

$2.50 \times 10^{-6}$

$$
L^{*}=\frac{C_{1}}{C_{2} D S}
$$

$\mathrm{C}_{1}=$ activity leached per gram of glass in one week

$c_{2}=$ initial activity per gram of glass

$\mathrm{D}=$ density in grams per $\mathrm{cm}^{3}$

$\mathrm{S}=$ surface area in $\mathrm{cm}^{2}$ per gram

Glass Particle Size: $35 / 45$ mesh 


\section{TABLE 7}

Leaching Rates for Purex Type Phosphate Glass Containing $\mathrm{Ce}^{144}$ as a Tracer

$I^{*}$ in $\mathrm{cm}$ per week

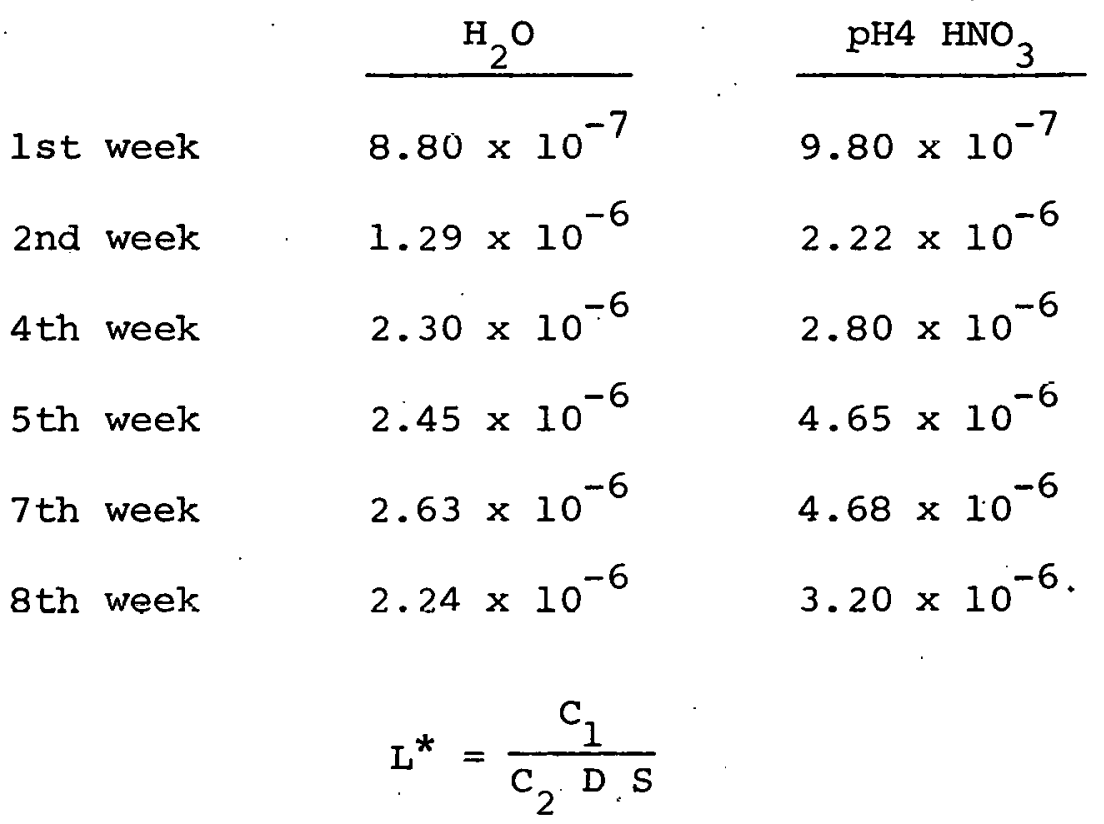

$c_{1}=$ activity leached per gram of glass in one week

$c_{2}=$ initial activity per gram of glass

D - density in grams per $\mathrm{cm}^{3}$

$S=$ surface area in $\mathrm{cm}^{2}$ per gram

Glass Particle Size: $35 / 45$ 


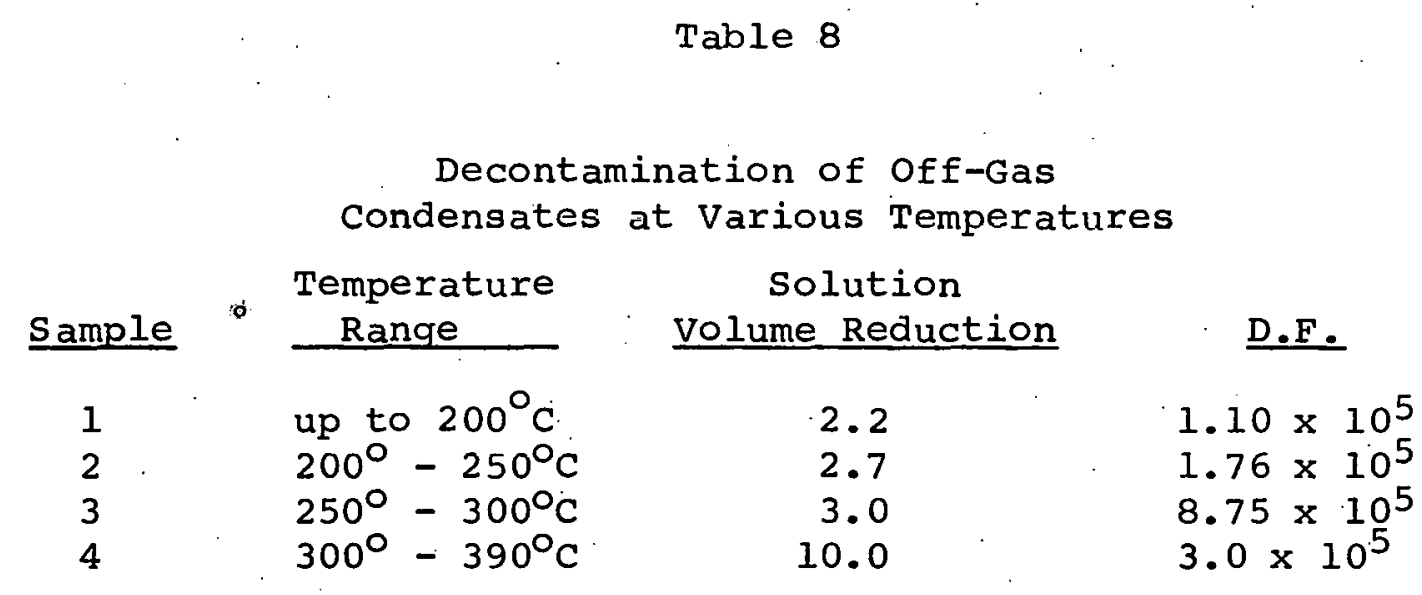

Average D.F. $1.13 \times 10^{5}$ 


\title{
LIST OF CAPTIONS
}

\author{
Figure $i$ - Bench-Scale Equipment \\ 2 - Schematic Fiow Sheet Phosphate Glass Process \\ 3 - Phosphate Glass Pilot Plant \\ 4. - Phosphate Glass Pilot Plant Platinum Melter \\ 5 - Hot Cell Glass Experiment Flow Sheet \\ 6 - Hot Cell Equipment \\ 7 - Radioactive Glass Produced in Hanford Cell \\ Experiments \\ 8 - Purex Phosphate Glass Composition Chart \\ 9 - Redox Phosphate Glass Composition \\ 10 - Alumina Crucible for Phosphate Glass Pilot \\ Plant \\ 11 -Corrosion of Platinum Alloys by Phosphate \\ Glass at $1200^{\circ} \mathrm{C}$ Exposure Time $=\approx 3000$ Hours \\ 12 -Reduction of $\mathrm{SO}_{3}$ by $\mathrm{CO}+\mathrm{A}$ ir Flame
}




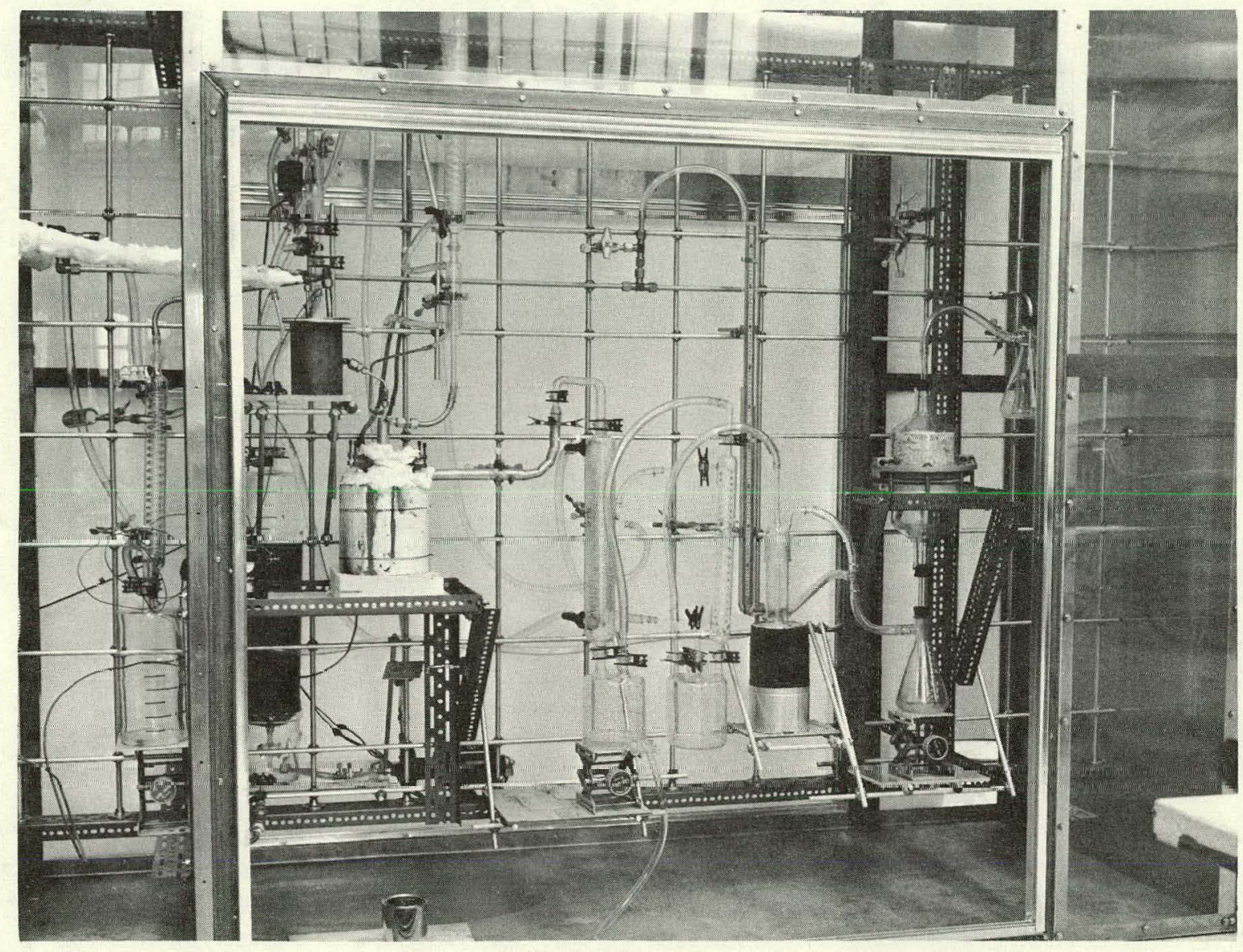

Figure 1 - Bench-Scale Equipment 


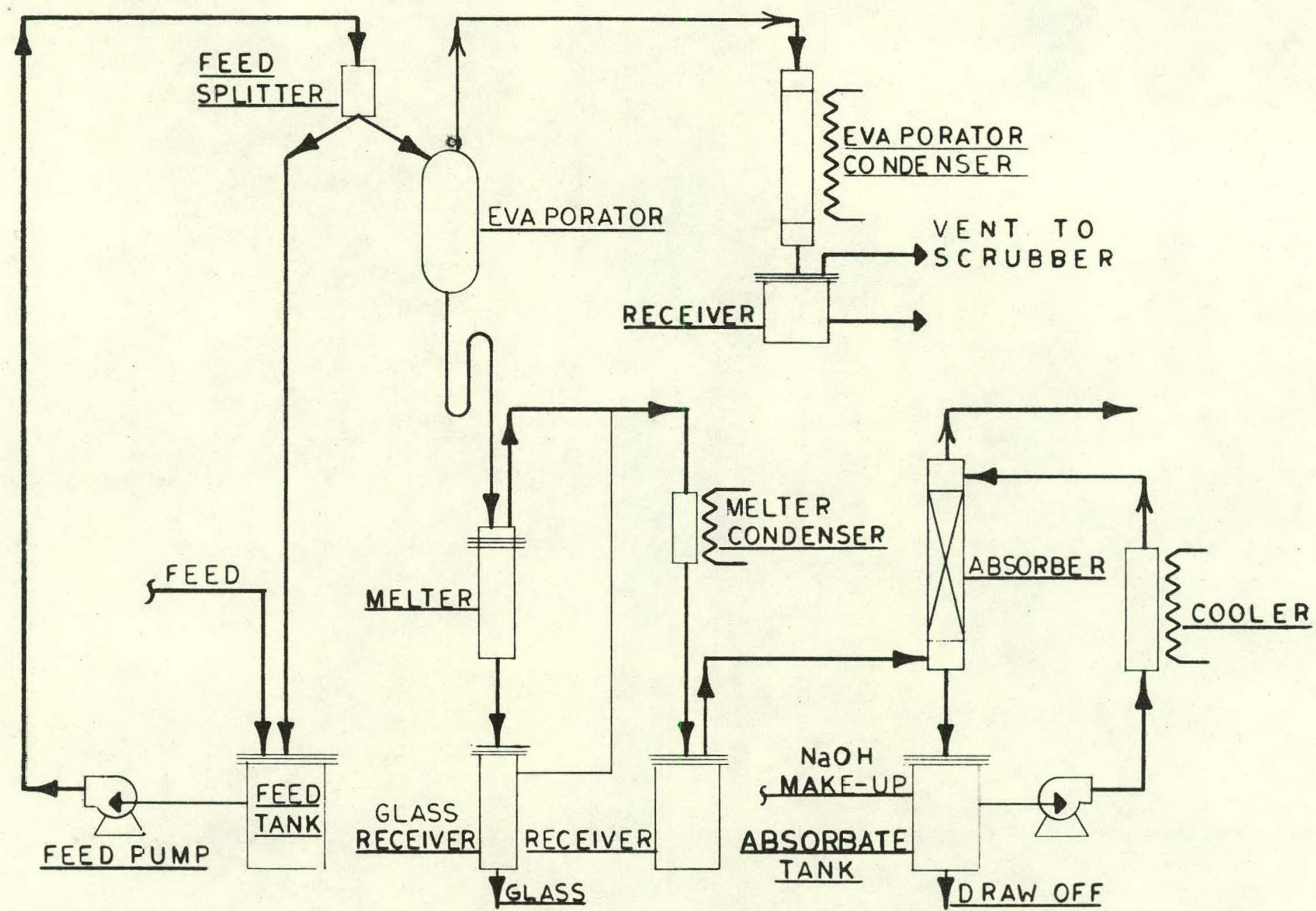

Figure 2 - Schematic Flow Sheet

Phosphate Glass Process 


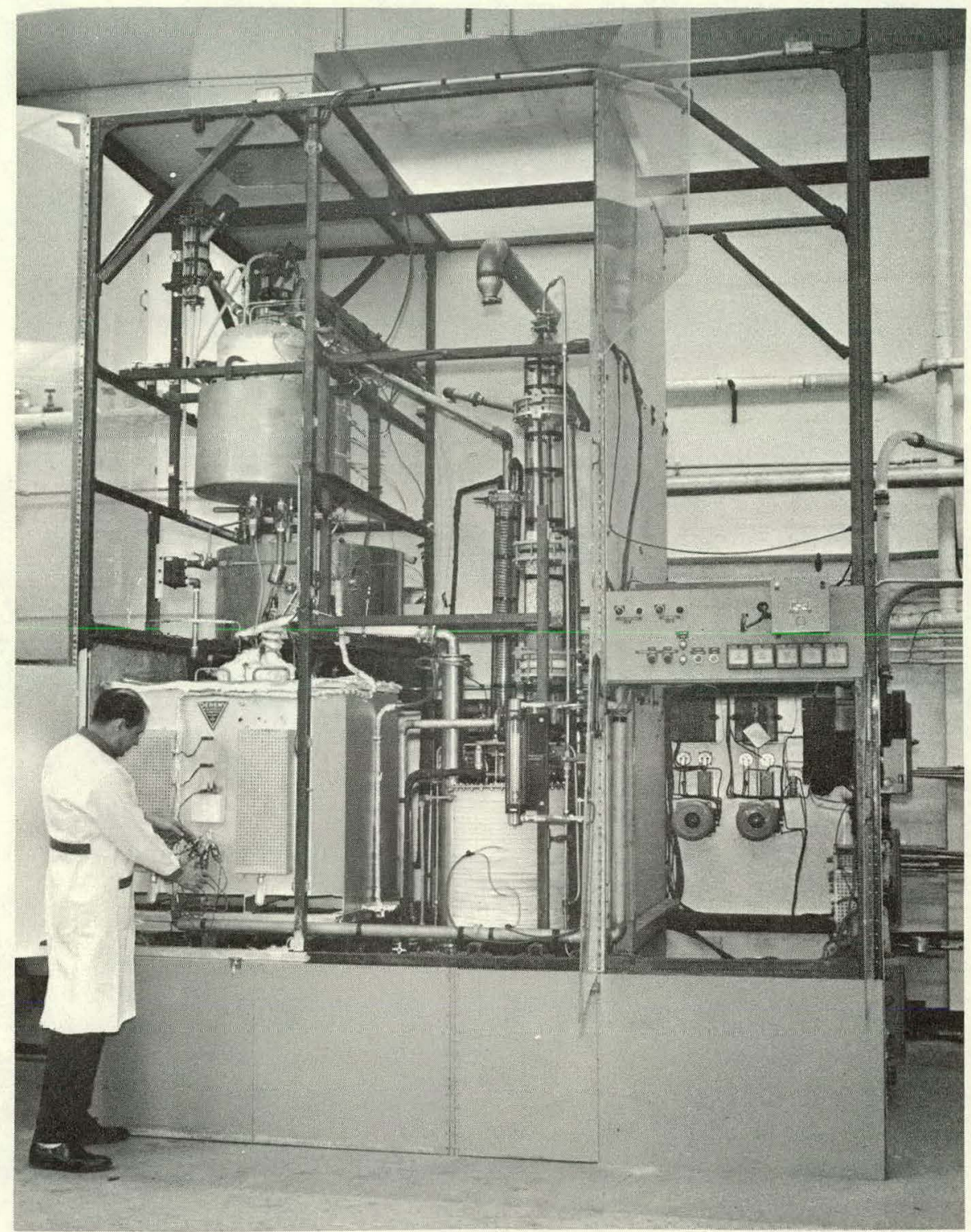

Figure 3 - Phosphate Glass Pilot Plant 

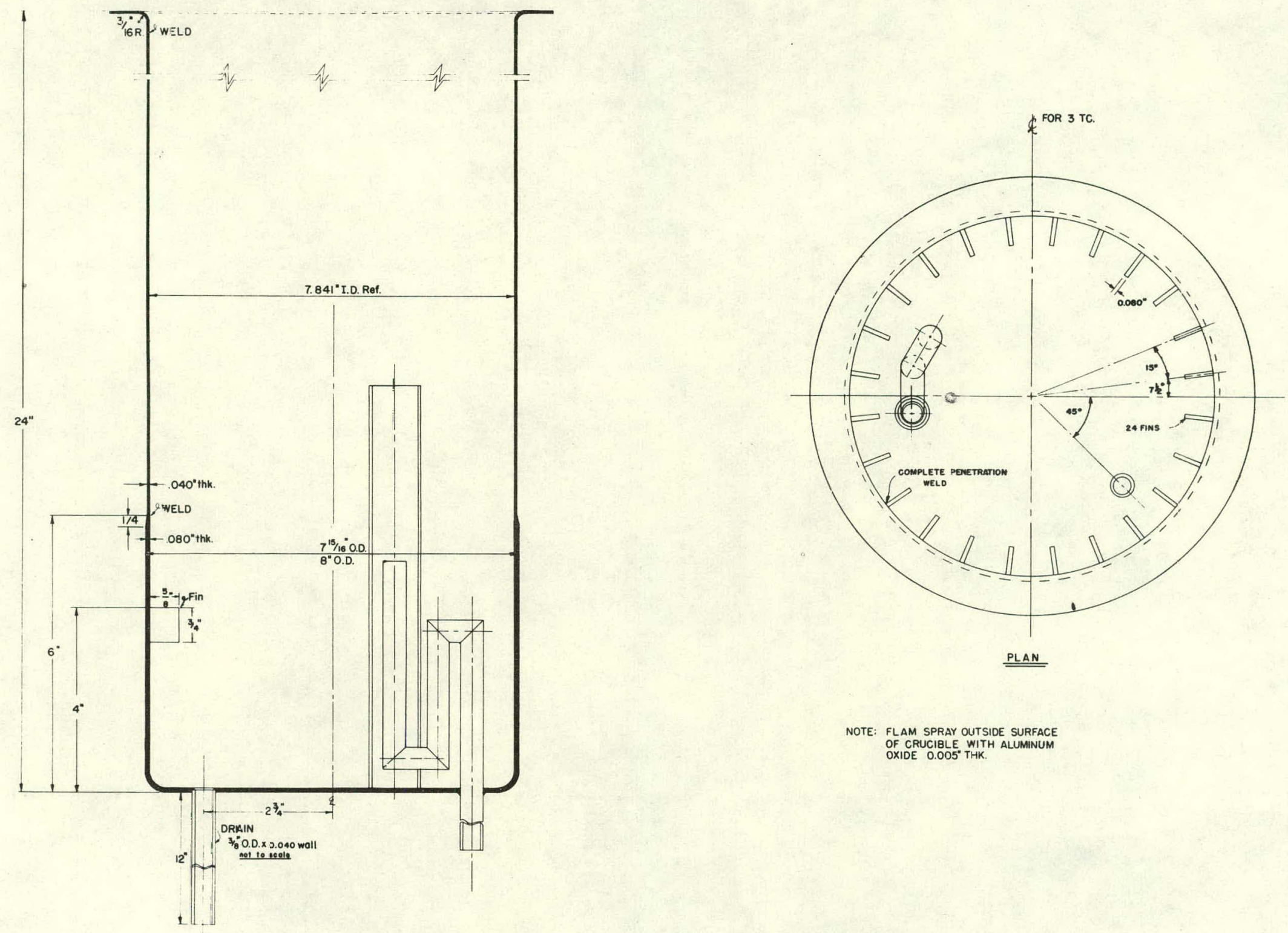

NOTE: FLAM SPRAY OUTSIDE SURFACE OF CRUCIBLE WITH ALUMINUM
OXIDE 0.005 "THK.

Figure 4 - Phosphate Glass Pilot Plant P-atinum Melter 
HOT CELL GLASS EXPERIMENT FLOW SHEET

SCHEME I

SCHEME II

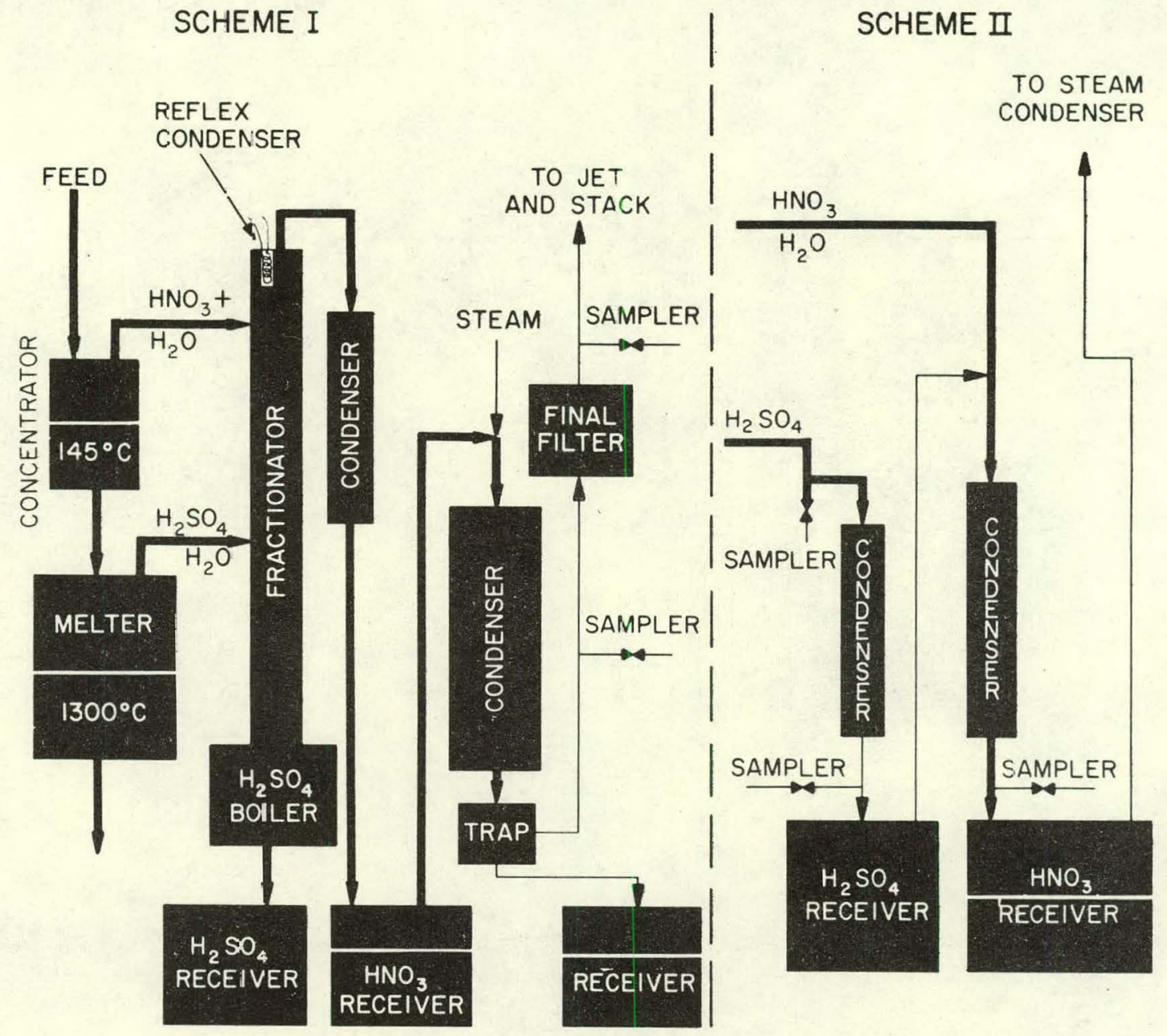

Figure 5 - Hot Cell Glass Experiment Flow sheet 


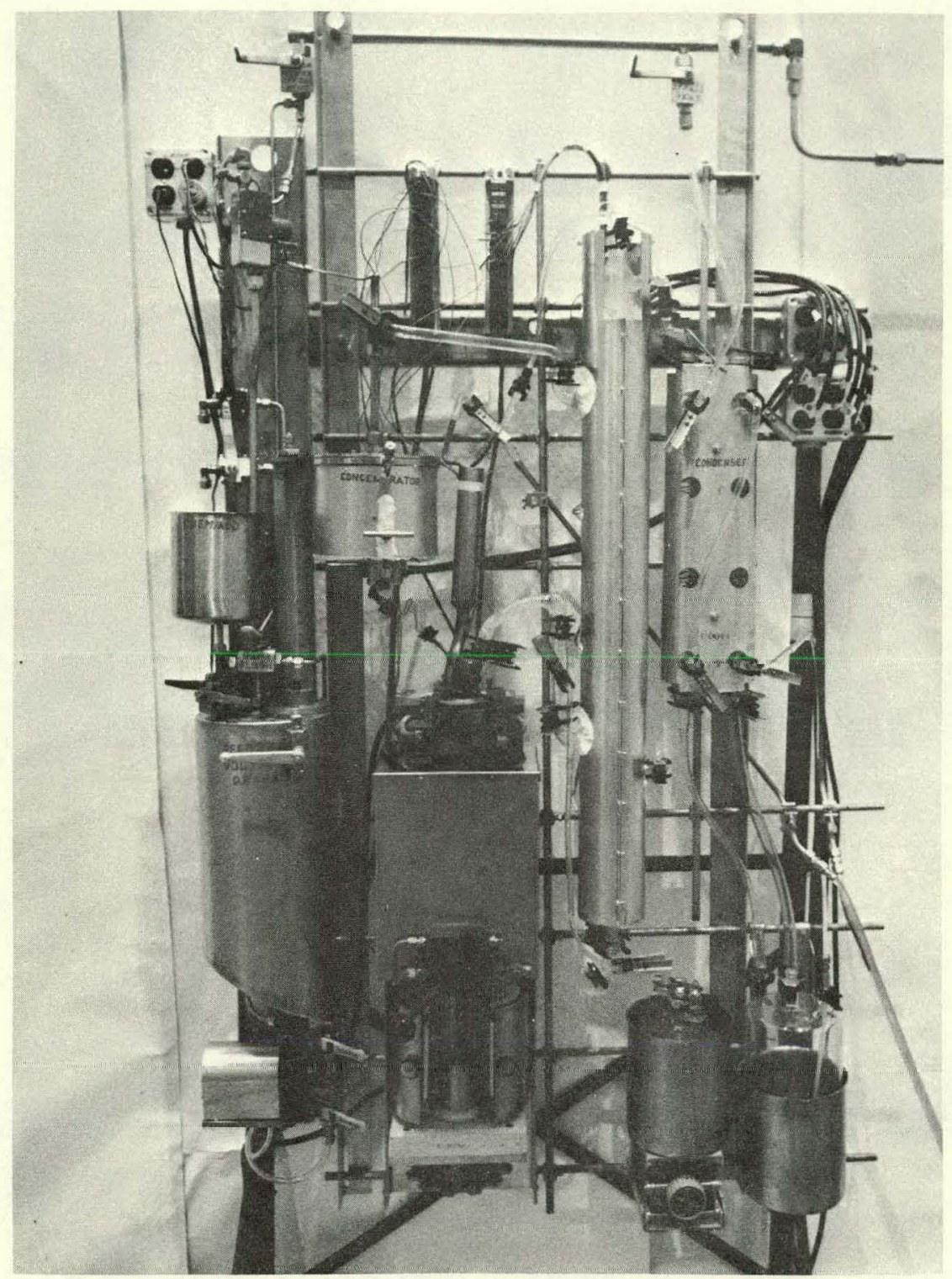

Figure 6 -Hot Cell Equipment 


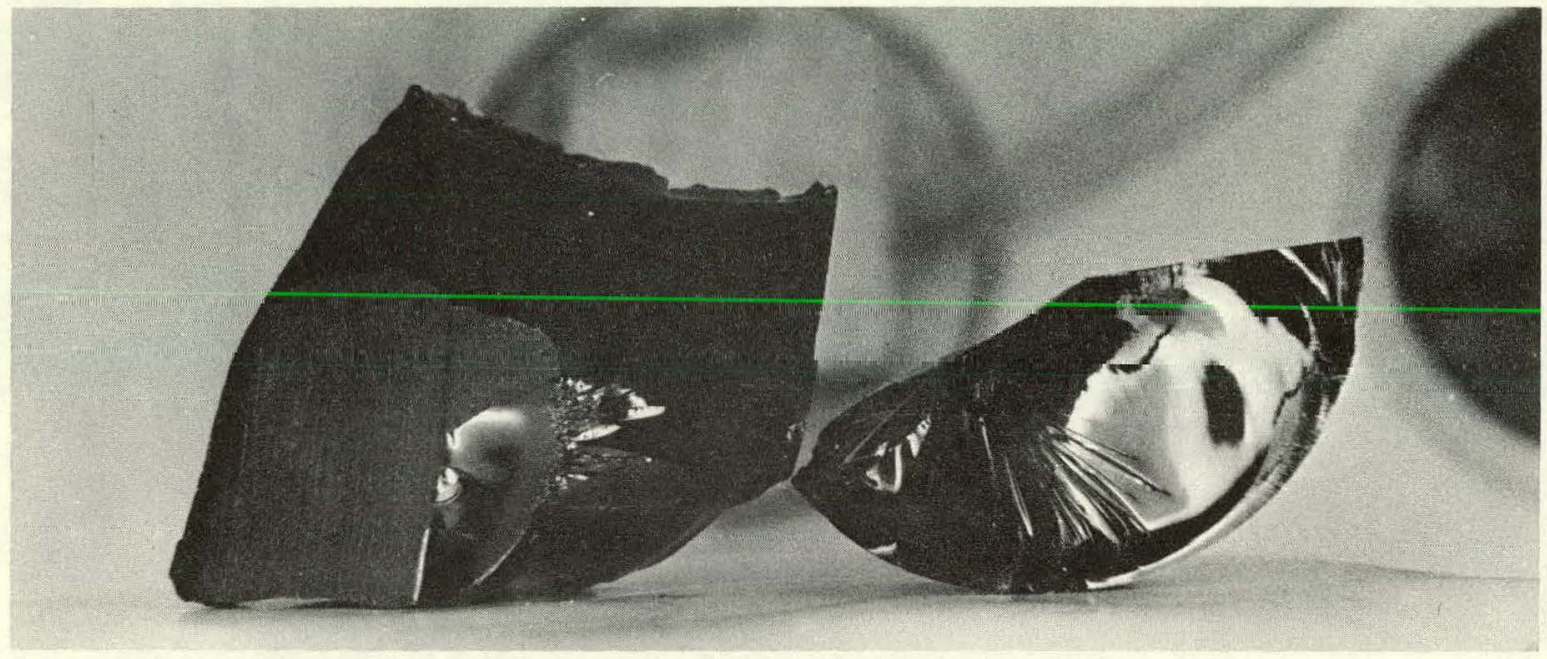

Figure 7 - Radioactive Glass Produced in Hanford Cell Experiment 


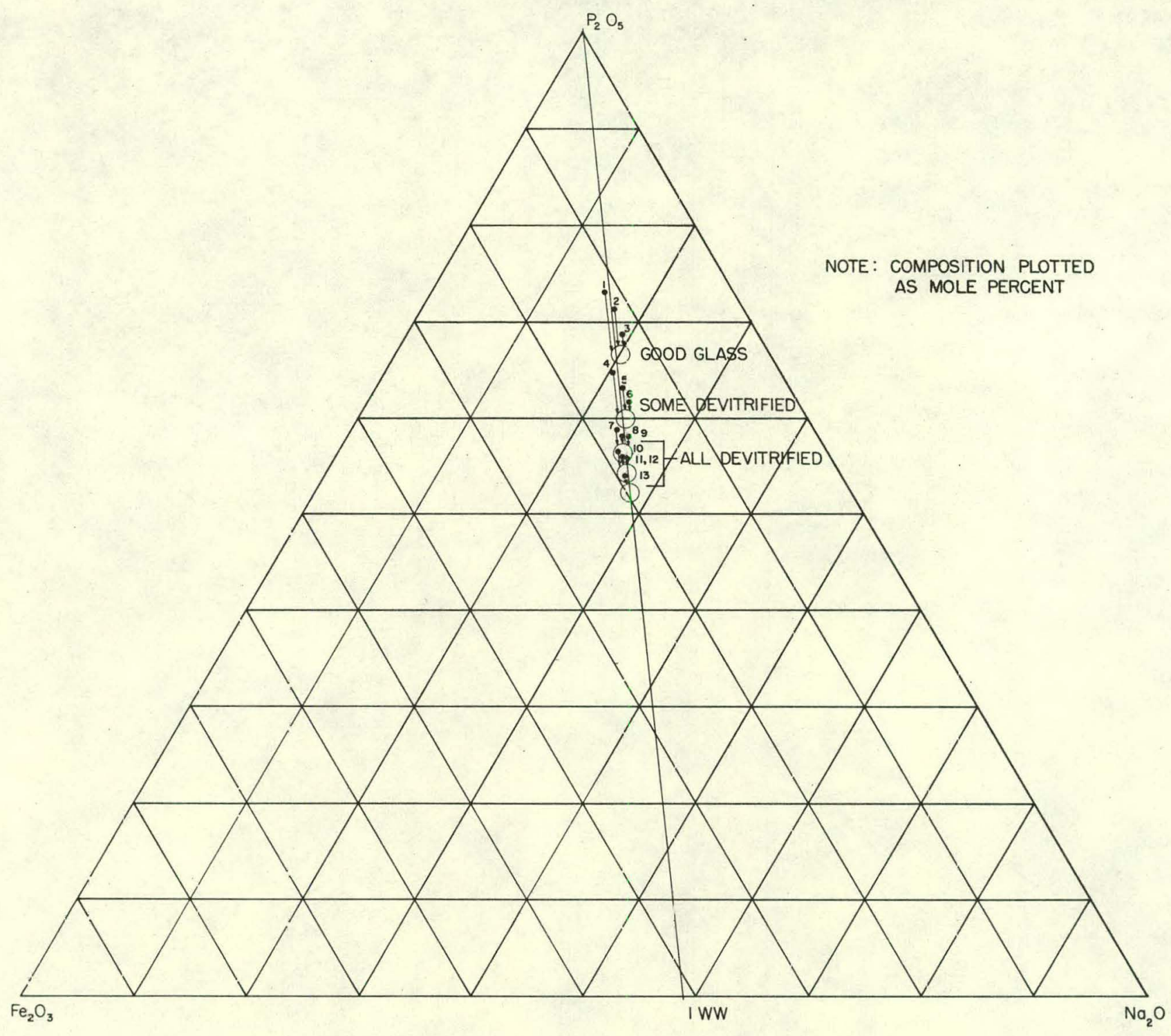

Figure 8 - Pure Phosphate Glass Composition Chart 


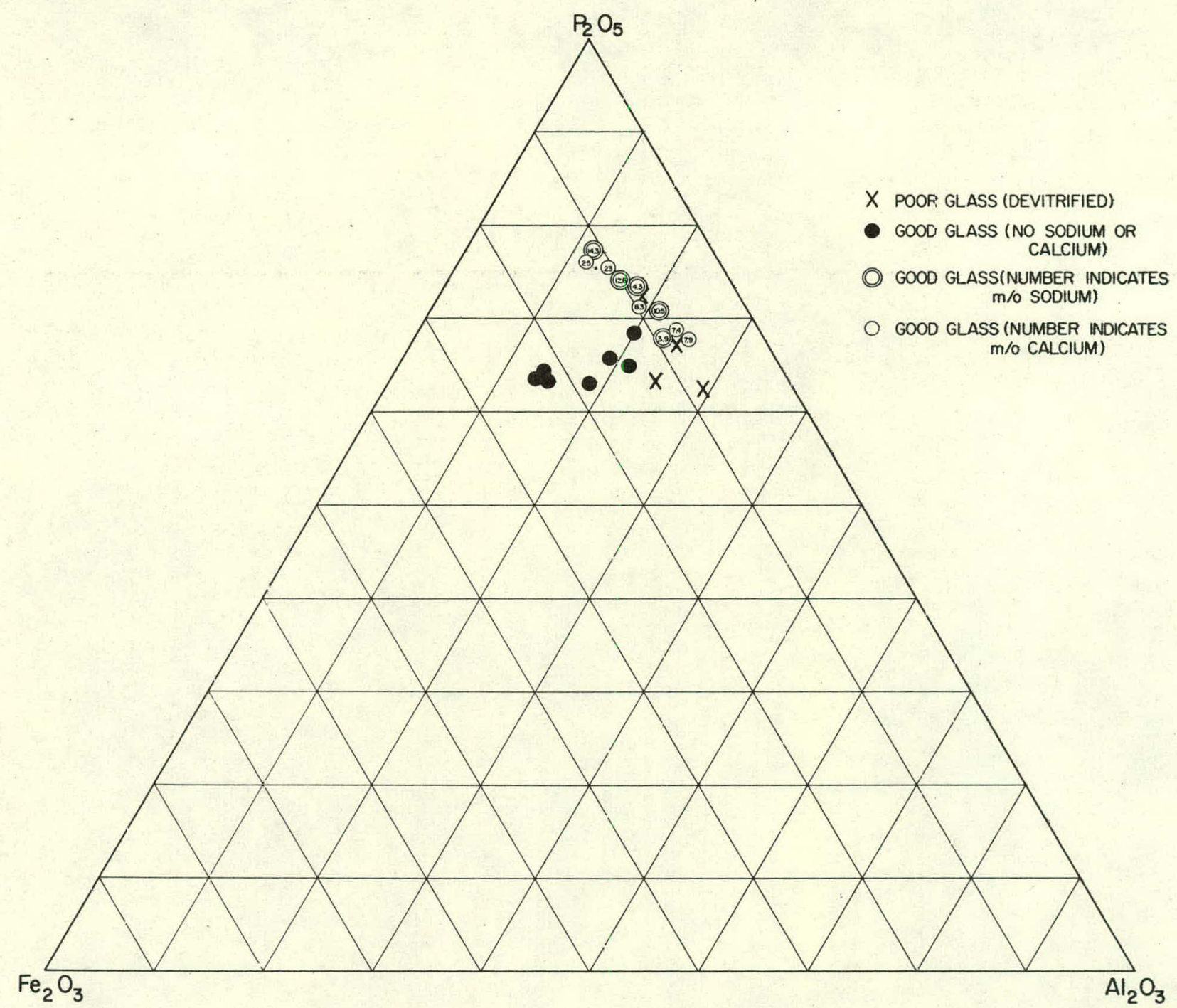

Figure 9 - Redox Phosphate Glass Composition 


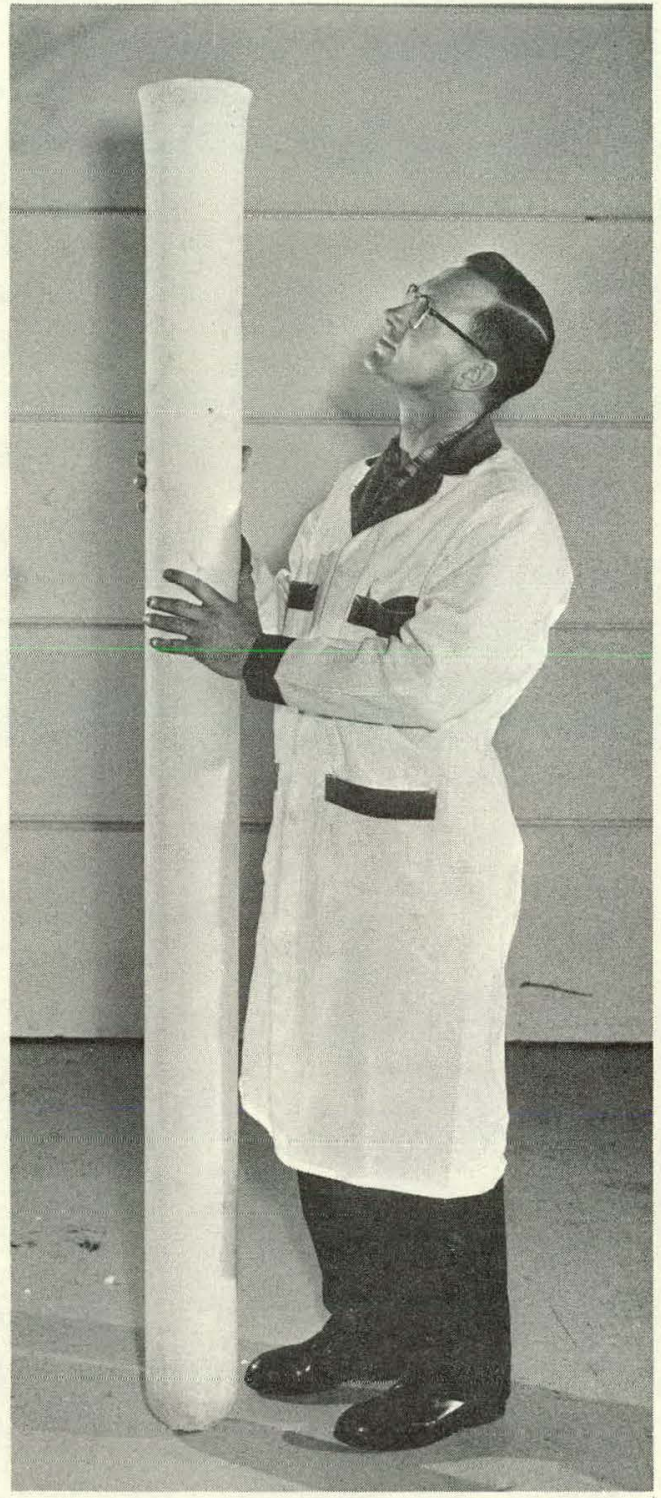

Figure 10 - Alumina Crucible for Phosphate Glass Pilot Plant 
CORROSION OF PLATINUM ALLOYS BY PHOSPHATE GLASS AT $1200^{\circ} \mathrm{C}$ EXPOSURE TIME $=\sim 3000$ HOURS
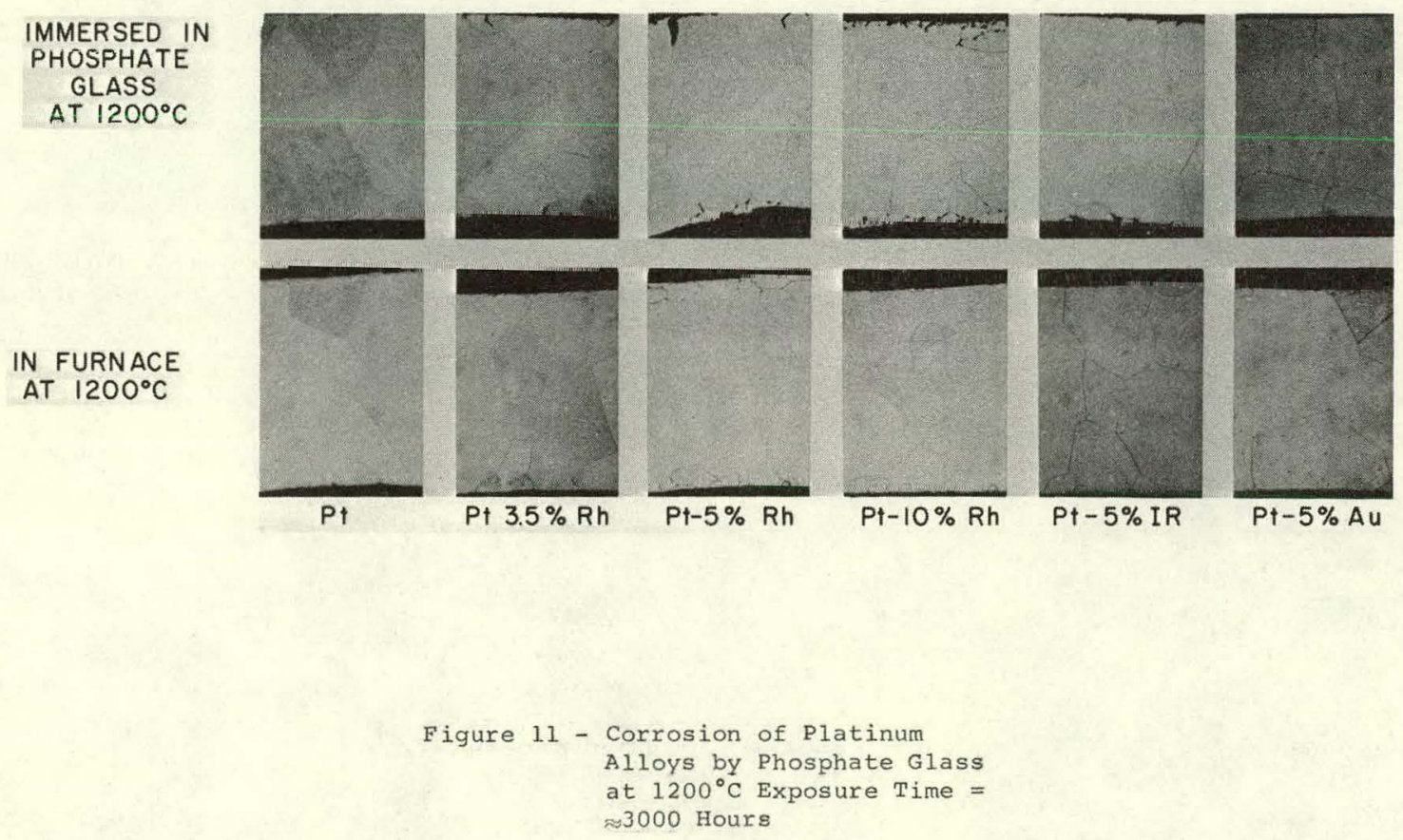

at $1200^{\circ} \mathrm{C}$ Exposure Time = $\approx 3000$ Hours 


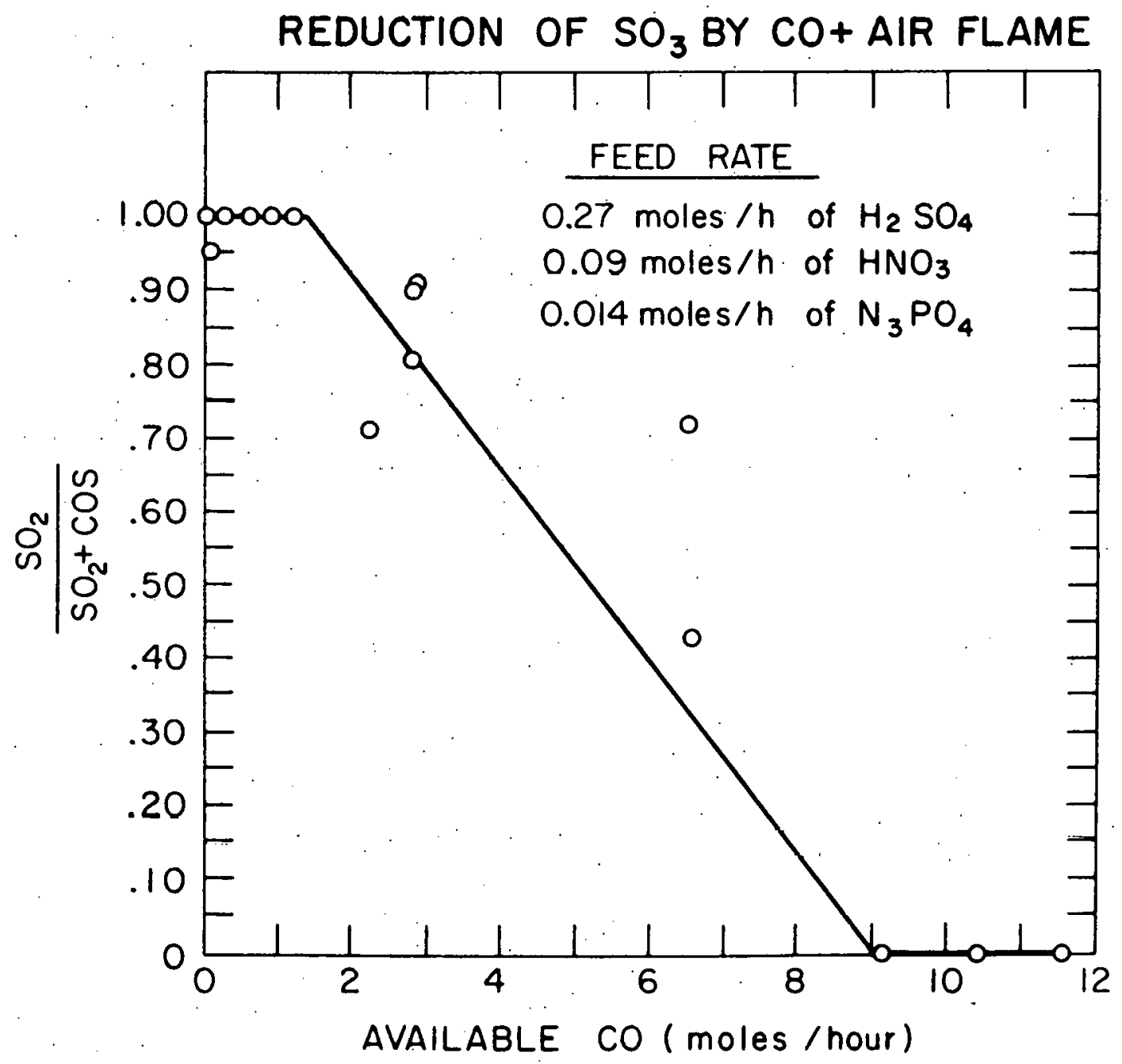

FIGURE 12 